\title{
PENGOLAHAN AMPAS TAHU SEBAGAI PAKAN ALTERNATIF UNTUK IKAN BANDENG DI DESA KEDUNG SEKAR KECAMATAN BENJENG KABUPATEN GRESIK
}

\author{
Heri Susanto ${ }^{1}$ \\ Universitas Wijaya Putra \\ herisusanto@uwp.ac.id
}

\begin{abstract}
Abstrak
Pengolahan ampas tahu ini dilaksanakan untuk memberikan pelatihan penggunaan limbah tahu untuk budidaya ikan bandeng yang bertujuan (1) pengolahan limbah menjadi pakan yang berbahan dasar ampas tahu (2) pemberian pakan ikan bandeng yang berasal dari bahan organik sehingga ikan bandeng akan berkembang dengan baik(3) memberikan efisiensi biaya budidaya ikan bandeng berdampak pada pendapatan petani tambak. Metode yang diterapkan adalah Agribisnis Integrated pemanfaatan limbah Ampas Tahu yang berbahan dasar dari kedelai untuk dijadikan pakan ikan/pelet bandeng organik. Mengingat begitu melimpahnya limbah Ampas Tahu yang tidak diolah dan tidak mempunyai nilai jual, setelah pengolahan menjadi pelet mempunyai nilai jual dari biaya produksi hargaRp. 5000/kg dibandingkan harga pellet bandeng dipasaran mencapai Rp. 12.000 - Rp. 18.000/kg. Dengan pengolahan pakan alternatif ini bisa menekan biaya budidaya bandeng lebih dari $60 \%$ terhitung biaya perhektar membutuhkan $600 \mathrm{Kg} /$ hapakan dengan harga rata - rata Rp. 15.000sehingga total biaya Rp. 9.000.000,/ha setelah pemanfaatan limbah Ampas Tahu biaya menjadi Rp. 3000.000,-/ha. Disamping itu juga pengabdian kepada masyarakat ini sedikit dapat turut serta memberikan kontribusi terhadap program pemerintah yaitu masyarakat bebas sampah.
\end{abstract}

Kata Kunci : pakan alternatif, ampas tahu, efisiensi

\section{PENDAHULUAN}

Salah satu desa di Kabupaten Gresik yang memiliki potensi perikanan dan kelautan adalah Desa Kedungsekar. Sistim budidaya perikanan yang dikembangkan di desa ini adalah sistim budidaya air payau yakni budidaya di tambak ikan dan udang. Pada umumnya ikan yang dibudidayakan masyarakat petani adalah udang dan ikan bandeng (Chanos chanos) (Dinas Perikanan dan Kelautan Gresik 2013). Hal ini karena ikan bandeng merupakan komoditas yang memiliki keunggulan komparatif dan strategis dibandingkan dengan komoditas perikanan air payau lainnya, karena pertama prefensi masyarakat untuk mengkonsumsi ikan cukup tinggi, kedua merupakan sumber protein hewani yang potensial bagi pemenuhan gizi masyarakat, ketiga kebutuhan prasyarat hidup ikan bandeng yang kurang memerlukan kelayakan yang tinggi dan toleran terhadap perubahan kualitas lingkungan. Produksi ikan bandeng yang dihasilkan oleh petambak masyarakat mencapai 300-450 $\mathrm{kg} /$ panen. Kendala yang dihadapi oleh petambak masyarakat dalam pengembangan perikanan payau terutama masalah harga pakan yang mahal sehingga keuntungan yang dihasilkan masih sangat rendah.

Petambak ini diprakarsai oleh beberapa masyarakat yang ingin berkembang, jumlah anggota 
petambak berjumlah 10 orang. Hasil wawancara dengan beberapa petani ikan bandeng bahwa bandengi produksi yang mereka peroleh belum memberikan keuntungan yang memuaskan karena bandengi produksi hampir sama dengan biaya yang digunakan selama pemeliharaan. Hal ini karena petani lebih mengandalkan pakan buatan pabrik yang harganya semakin mahal. Untuk mengatasi harga pakan yang semakin mahal, petani telah berupaya memberikan pakan alternative yang ketersediaannya di lapangan melimpah.

Pakan alternatif yang biasa digunakan oleh para petani ikan berupa ampas tahu, dedak dan rebon. Pemberian pakan alternatif tersebut hanya diberikan secara terpisah, tanpa di sertai teknik meracik pakan alternatif. Hal ini ternyata membutuhkan waktu pemeliharaan yang lebih lama dan belum mampu meningkatkan produksi secara optimal. Untuk itu masih terbuka peluang untuk peningkatan hasil melalui penerapan teknologi tepat guna dalam budidaya ikan bandeng di tambak.

Bidang yang akan diselesaikan bersama adalah : Pembuatan Pakan pakan ikan bebrbentuk pellet Berbasis Sumberdaya lokal melalui : satu. Pemilihan bahan baku untuk pakan, dua, teknik pencampuran dan pencetatan, tiga, Pengujian bandengi biologis pakan, empat, Pengemasan pakan dan lima, Menejemen pemberian pakan enam, Perijinan untuk produksi pakan.

Permasalahan yang sering di hadapi oleh petambak tambak bandeng adalah keterbatasan pengetahuan dan teknologi terutama pembuatan pakan ikan yang sesuai dengan standar kebuthan, bentuk pakan yang sesuai dengan kondisi di wilayahnya, ketersediaan bahan baku yang dapat digunakan sebagai pakan untuk ikan bandeng.

Pengamatan di lapangan, teridentifikasi beberapa permasalahan, antara lain:

Pertama mahalnya harga pakan buatan pabrik yang berdampak pada rendahnya pendapatan mitra.

Kedua rendahnya produksi ikan bandeng yang berdampak pada rendahnya pendapatan mitra.

Ketiga kurangnya wawasan mitra dalam menerapkan teknologi tepat guna dalam usaha budidaya ikan bandeng.

Keempat kurangnya ketrampilan mitra dalam menerapkan teknologi tepat guna dalam usaha budidaya ikan bandeng, yaitu teknik meracik pakan alternatif.

Solusi yang ditawarkan, pertama memberikan penyuluhan tentang penerapan ilmu dan teknologi dalam pembuatan pakan Ikan berbasis sumber daya lokal yang tersedia, kedua meberikan pelatihan tentang pemilihan bahan pakan, teknik penyusunan formulasi bahan pakan, teknik pencampuran bahan, produksi pakan dalam pellet, pengemasan, pengujian mutu pakan, pengemasan pakan; ketiga memberikan pelatihan manajemen pemberian pakan dan manajemen pengelolaan.

\section{METODE}

Metode yang digunakan dalam kegiatan pengabdian masyarakat ini terdiri dari dua macam kegiatan yaitu :

Pertama Kegiatan Ceramah

Kegiatan ceramah diperlukan untuk memberikan dasar pemahaman mengenai:

Peningkatan partisipasi dan kinerja produksi mitra dalam rangka penyediaan bahan baku dalam pembuatan pakan pellet

Mitra pembudidaya ikan Bandeng di desa Kedungsekar Kabupaten Gresik mampu membuat pakan ikan yang bersumber dari ampas tahu yang akan digunakan sebagai pakan pada budidaya ikan Bandeng (Chanos chanos) di Tambak.

Menghasilkan pakan ikan Bandeng (Chanos chanos) yang berasal dari ampas tahu sehingga dapat menurunkan biaya produksi ikan Bandeng (Chanos chanos) sebesar $15-20 \%$ jika menggunakan pakan komersial.

Meningkatkan pendapatan mitra pembudidaya ikan Bandeng (Chanos chanos) sebesar 15-20\% untuk satu siklus pemanenan.

Meningkatkan pengetahuan mitra dalam menyediakan pakan ikan yang berasal dari ampas tahu.

Kemampuan manajemen dan Wirausaha dengan membantu kelompok untuk pembuatan pakan dalam upaya mendapatkan hasil yang lebih baik.

Kedua Kegiatan Praktek

Kegiatan yang dilakukan pada tahapan berkaitan dengan kegiatan operasional pembuatan 
pakan ikan yang berasal dari pemanfaatan ampas tahu, yaitu :

Mengumpulkan bahan baku berupa ampas tahu yang diperoleh dari sisa produksi para pembuat tahu yang ada di Provinsi Gorontalo.

Membuat pakan ikan yang berasal dari ampas tahu. Tahapan pembuatan pakan ikan yang berasal dari ampas tahu, sebagai berikut : mengeringkan ampas dengan cara penjemuran selama 1 -2 hari atau hingga kadar air yang tersisa $10 \%$, mencampur bahan pembuatan pakan ikan yang terdiri dari : Ampas Tahu (70 \%), Ampas Kelapa (10\%), Tepung Ikan (10\%), Tapioka (5\%), Air (5\%), Pencetakan pakan ikan, Penjemuran pakan ikan yang telah di cetak

Pemberian pakan ikan yang berasal dari ampas tahu pada budidaya ikan Bandeng (Chanos chanos) di desa Kedungsekar Kabupaten Gresik.

\section{HASIL DAN PEMBAHASAN}

\section{Pemanfaatan pakan alternatif}

\section{Pakan alternatif}

Pakan alternatif ialah pakan ikan yang berasal dari limbah atau hewan lain yang tidak dimanfaatkan untuk bahan pakan buatan (Khairuman dan Amri, 2002). Pemberian pakan alternatif pada ikan bandeng yang dibudidaya di tambak mempunyai peranan penting untuk meningkatkan produksi. Hal ini karena jika hanya mengandalkan pakan buatan pabrik yang saat ini harganya semakin mahal maka dapat mempengaruhi pendapatan petani ikan bandeng. Ikan bandeng membutuhkan pakan yang mengandung protein $20-$ $25 \%$, karbohidrat sebanyak $25 \%$, lemak $6-8 \%$, vitamin $0,5-10 \%$ dan mineral $0,25-0,5 \%$.

Jenis pakan alternatif antara lain : rebon, ampas tahu dan dedak halus. Jenis-jenis pakan tersebut bisa dijadikan makanan ikan karena masih mengandung gizi yang cukup untuk pertumbuhan ikan. Selain itu pula mudah di dapat dan harganya relatif murah.

Beberapa jenis pakan alternatif beserta kandungan gizinya antara lain:

Ampas Tahu
Ampas tahu adalah limbah pabrik tahu yang bahan dasar kedelai. Karena berbahan baku kedelai maka kandungan proteinnya masih cukup tinggi. Ampas tahu merupakan sumber karbohidrat dan protein. Ampas tahu ini mengandung protein 13,86$23,55 \%$, lemak $2,93-5,54 \%$, karbohidrat $26,92-$ $42,97 \%$, serat kasar 16,50-26,39\%, abu 3,33\% dan air 10,45-10,52\%. Ampas tahu dapat dimanfaatkan sebagai bahan baku pakan ikan dalam kondisi masih baik atau tidak busuk. Penggunaan sebagai pakan dapat dicampur dengan bahan tambahan pakan lainnya atau bisa juga diberikan secara langsung pada ikan yang dibudidayakan.

Dedak Halus

Dedak halus merupakan pemisahan dari dedak kasar dengan beras yang butirannya sangat halus. Dedak halus ini mudah diperoleh dari tempat penggilingan padi dan harganya relatif murah. Hasil pengujian kandungan nutrisi dedak halus dari berbagai referensi menunjukkan bahwa dedak halus mengandung protein $9,6-10,86 \%$, lemak 0,12$11,19 \%$, karbohidrat $34,18-34,73 \%$, serat kasar $10,73-45,15 \%$, abu $0,24 \%$ dan air $10,71-12,47 \%$ (Sahwan, 2003).

\section{Tepung Ikan}

Tepung ikan berasal dari ikan sisa atau buangan yang tidak dikonsumsi oleh manusia, atau sisa pengolahan industri makanan ikan, sehingga kandungan nutrisinya beragam, tapi pada umumnya berkisar antara $60-70 \%$.

Dari hasil di lapangan ternyata petani ikan bandeng termasuk mitra belum pernah memanfaatkan pakan alternative.

\section{Penggunaan teknologi tepat guna dalam perikanan}

Untuk pengembangan usaha budidaya ikan bandeng di masyarakat, dimana pemahaman mereka tentang budidaya secara umum masih rendah, mutlak diperlukan pendampingan teknologi agar permasalaha-permasalahan yang muncul dapat di bantu pemecahannya. Tingkat teknologi yang akan di gunakan dalam pengelolaan budidaya perikanan air tawar, belum tentu sama untuk setiap tempat. Penentuan tingkat teknologi akan di pengaruhi oleh: potensi lahan yang tersedia, kapasitas SDM yang 
tersedia, daya dukung lingkungan, dan sarana dan prasarana utama maupun pendukung yang tersedia.

Berdasarkan permasalahan yang dihadapi mitra, dan memperhatikan potensi lahan yang tersedia, kapasitas SDM, daya dukung lingkungan, dan sarana dan prasarana yang tersedia maka teknologi tepat guna yang dapat diterapkan pada mitra kelompok usaha budidaya ikan bandeng adalah teknik meracik pakan alternatif. Ini karena pakan alternatif yang dimanfaatkan tersedia di sekitar daerah budidaya dan harganya relatif murah.

\section{Memberikan wawasan pentingnya penerapan teknik meracik pakan alternatif}

Pakan alternatif yang biasa digunakan oleh para petani ikan berupa ampas tahu, dan dedak memiliki kandungan gizi yang berbeda-beda sehingga pemanfaatannya sebagai pakan perlu di racik terlebih dahulu dengan memperhatikan keseimbangan zat-zat gizi yang dibutuhkan untuk pertumbuhan ikan. Ikan bandeng membutuhkan pakan yang mengandung protein 20-25\%, karbohidrat sebanyak $25 \%$, lemak $6-8 \%$, vitamin $0,5-10 \%$ dan mineral $0,25-0,5 \%$. Oleh karena itu dalam meracik pakan perlu didasarkan kebutuhan protein ikan bandeng sehingga pertumbuhannya menjadi optimal. Hasil penelitian Gani (2008) menunjukkan bahwa campuran pakan alternatif yang didasarkan pada kandungan protein 25\% dapat meningkatkan pertumbuhan ikan bandeng secara signifikan.

Beberapa pakan buatan sendiri diakui masih kurang berkualitas dari pakan buatan pabrik tapi tidak menutup kemungkinan pakan buatan sendiri lebih baik, lebih segar jika bahan-bahan pembuatan pakan tersedia dan mutu yang baik. Pakan yang baik memenuhi nutrisi ikan. Mengenal kebutuhan nutrisi ikan merupakan landasan dalam pembuatan pakan ikan sendiri, setiap ikan membutuhkan nilai gisi yang berbeda, kebutuhan protein, lemak dan serat ikan nila atau tilapia berbeda dengan ikan lele. Ikan lele memerlukan lebih sedikit nilai nutrisi dibanding dengan ikan nila, gurame, ikan mas dan sebagainya. Pakan yang memiliki keseimbangan protein, lemak, dan serat untuk kebutuhan ikan tertentu akan memacu pertumbuhan ikan yang cepat besar, akan tetapi bila nutrisi yang dibutuhkan ikan kurang maka pertumbuhan ikan akan lambat berakibat pada biaya dan waktu panen yang cukup lama. Dalam membuat pakan buatan untuk ikan, hal pertama yang harus dipertimbangkan, adalah persyaratan bahan baku untuk pakan, yaitu : pertama bahan baku pakan tidak boleh bersaing dengan bahan makanan manusia. Bila manusia banyak membutuhkannya, bahan baku ini tidak boleh diberikan kepada ikan. Kedua, bahan baku ini harus tersedia dalam waktu lama, atau ketersediaannya harus kontinyu. Bahan baku yang pada suatu saat ada dan kemudian lenyap, harus dihindari. Padi yang diproduksi secara massal dan nasional, tentu menyebabkan ketersediaan dedak dan bekatul untuk ternak juga melimpah ruah. Sebaliknya untuk bahan baku yang diproduksi secara terbatas, juga akan menghasilkan bahan secara terbatas pula. Ketiga, harga bahan baku; walaupun bisa digunakan, tapi bila harganya mahal maka penggunaan bahan atau peran bahan baku itu sebagai bahan baku sudah tersisihkan. Sebenarnya murah atau mahalnya bahan baku itu harus dinilai dari manfaat bahan itu, yang merupakan cermin dari kualitas bahan tersebut. Tepung ikan, misalnya harganya memang mahal, tetapi bila dibandingkan dengan kandungan proteinnya yang tinggi dan kelengkapan asam aminonya, maka penggunaan tepung ikan menjadi murah. Keempat, kualitas gizi bahan baku, menjadi persyaratan penting lainnya. Walaupun harganya murah, banyak terdapat di Indonesia dan ketersediaannya kontinyu, tetapi bila kandungan gizinya buruk, tentu bahan baku ini tidak dapat digunakan. Kelima, rasa dan aroma pakan. Pakan yang dibuat harus memiliki rasa yang enak dan aroma yang disukai ikan. Pakan seperti ini akan habis dimakan ikan sehingga pakan tidak terbuang dan membusuk didalam kolam. Pemakaian bahan baku yang menyebabkan rasa pakan tidak enak perlu dihindari. Dalam menyusun formulasi pakan ikan komersial, perhitungan mutlak diperlukan untuk menentukan komposisi paka yang sesuai degan standar kebutuhan nutrisi ikan. Pada prinsipnya perhitungan ini mempunyai tujuan untuk mendapatkan pakan yang ekonomis, layak nutrisi dan disenangi oleh ikan. 
Alat dan bahan yang digunakan pada pembuatan pakan ikan alternative dngan mmenggunakan bahan bahan limbah dapat dilihat pada Tabel berikut :

Tabel 1. Alat dan Bahan yang digunakan

\begin{tabular}{|l|l|}
\hline \multicolumn{1}{|c|}{ Alat } & \multicolumn{1}{c|}{ Bahan } \\
\hline Loyang plastik & Tepung Ampas tahu \\
\hline Sendok kayu besar & Tepung Ikan \\
\hline Panci/Dandang sedang & Tepung kanji \\
\hline Ember sedang & Bungkil kelapa \\
\hline Alas tangan & Garam \\
\hline Kompor & Vitamin \\
\hline Ember & Air \\
\hline Mixer & \\
\hline Alat penggiling & \\
\hline Timbangan & \\
\hline Saringan & \\
\hline
\end{tabular}

\section{Metode Kerja :}

Pembuatan Pellet :

Cara meracik bahan-bahan yang berupa tepung dimulai dari bahan yang paling sedikit. Kemudian dicampur bahan-bahan yang jumlahnya lebih banyak. Dalam wadah (ember) di letakan/ dicampur tepung ikan, tepung ampas tahu, tepung dedak, minyak ikan, premix, garam, dicampur hingga rata. Percampuran secara berangsur-angsur, sehingga peracian lebih sempurna.

Dalam wadah tersendiri, adonan perekat (tepung kanji) di seduh dengan air mendidih sedikit demi sedikit sehingga menjadi adonan yang kental.

Pada wadah yang telah tercampur pakan/pellet diberi adonan pengental sedikit demi sedikit sambil di remas berulang-ulang (di uleni) sampai tercampur rata. Apabila adonan masih basah dapat ditambahkan air adonan pengental sedikit demi sedikit sampai linak dan bisa di kepal "menjadi sulatan"

Setelah itu di cetak dengan alat penggilingan daging di tampung dalam wadah dan di potong-potong kurang lebih $3 \mathrm{~cm}$. Kemudian dijemur di panas matahari sambil dibolak balik dijemur sampai kering, keras dan mudah patah.

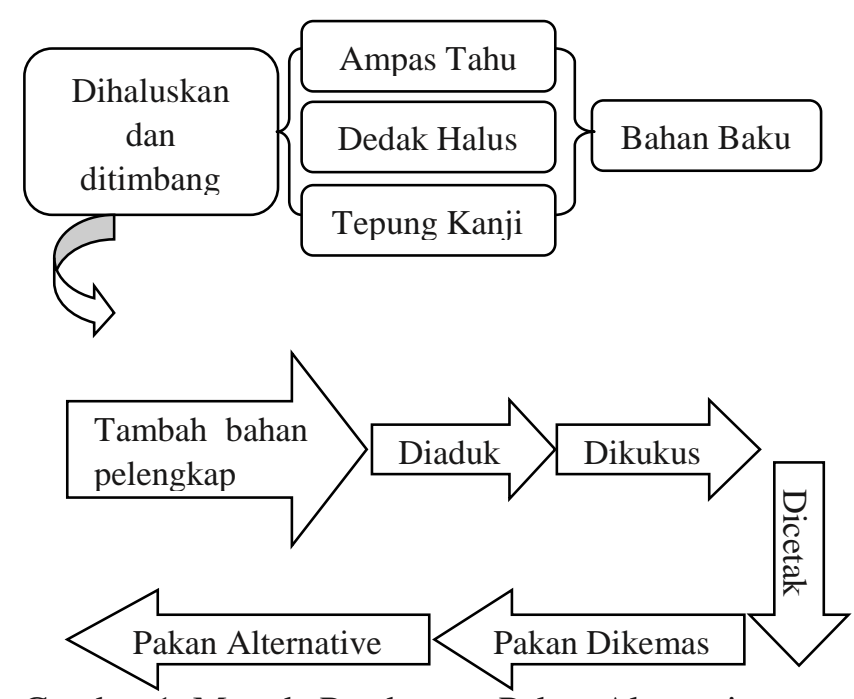

Gambar 1. Metode Pembuatan Pakan Alternative

\section{KESIMPULAN}

Berdasarkan hasil capai seperti yang diuraikan di atas maka kriteria keberhasilan yang telah ditentukan sebelumnya telah tercapai. Upaya untuk menanggulangi permasalahan pakan ini sehingga petani medapatkan hasil produksi yang maksimal. Oleh karena itu melalui kegiatan yang menanggulangi ketersediaan pakan, misalnya dengan memanfaatkan pakan alternatif. Kendala lain yang di alami petani dalam Teknik Budidaya Ikan Pemberian Pakan Alternatif adalah ketersediaan bibit.

Untuk penyempurnaan program maka perlu dilanjutkan program pengabdian ini melalui Program pendampingan. Agar pendampingan teknologi budidaya ikan dapat berjalan terencana dan terarah, maka harus terwadahi dalam sistem kelembagaan yang mendukung dan memperkuat pendampingan teknologi tersebut, yaitu dengan pola kemitraan melalui program pengabdian 


\section{UCAPAN TERIMAKASIH (Bila ada)}

Ucapan terimakasih disampaikan kepada Universitas Wijaya Putra yang telah memberikan kontribusi dalam pelaksanaan kegiatan. Ucapan terima kasih disampaikan kepada LPPM Universitas Wijaya Putra yang telah mengarahkan memfasilitasi PKM ini.

\section{REFERENSI}

Dinas Perikanan dan Kelautan Kabupaten Gresik, 2016. Kabupaten Gresik Dalam Angka 2016. Bappeda dan BPS Kabupaten Gresik.

Dinas Perikanan dan Kelautan Kabupaten Gresik,2016. Profil Perikanan dan Kelautan Kabupaten Gresik.
Gani, Nangsi. 2007. Pengaruh Campuran Pakan Alternatif Terhadap Pertumbuhan Ikan Nila. Skripsi. Tidak dipublikasikan. Universitas Negeri Gorontalo.

Khairuman dan Amri, 2002. Membuat Pakan Ikan Konsumsi. Jakarta: Agro Media Pustaka Sahami, S. 2003. Pengaruh Pemotongan Sirip Ekor Terhadap Pertumbuhan Ikan nila Hitam (Oreochromis niloticus, L) Di Jaring Apung. Skripsi IKIP Negeri Gorontalo.

Sahwan. M. Firdaus. 2003. Pakan Ikan dan Udang. Jakarta : Penebar Swadayadiperkenankan menggunakan footnote dan atau endnote. 